\title{
SOME OBSERVATIONS ON BIOLOGICAL PECULIARITIES OF THE SVALBARD FORM OF THE ARCTIC CHARR (SALVELINUS ALPINUS (L.))
}

\section{KILKA UWAG O BIOLOGICZNEJ ODMIENNOŚCI FORMY SVALBARDZKIIEJ GOLCA ARITTYCZNEGO (SALVELINUS ALPINUS (L.))}

\author{
Feculty of Marine Fisheries and Food Technology. \\ Academy of Agriculture, \\ Szczecin, Poland
}

\begin{abstract}
Morphological studies on the Svalbard form of Salvelinus alpinus (L.) revealed numerous differences between the form and populations of the species from other regions. A suggestion is put forward that the differences have resulted from different, sometimes extremely harsh, environmental conditions the Svalbard population is exposed to. A more restrictive protection of the species as an environmental indicator is postulated to be implemented on Svalbard.
\end{abstract}

The Arctic charr (Salvelinus alpinus (L.)) is a rather well known species and a subject of ample literature, dealing with both the populations occurring along the northern coasts of Europe and Asia (Berg, 1948; Essipov, 1952; Koljushev, 1971; Probatov, 1971; Savvaitova, 1976) and the stocks inhabiting drainage basins of Canada and Alaska (McPhail, 1961; Johnson, 1980).

On the other hand, the least attention has been so far paid to the Svalbard population of the species, regardless of studies by Gullestad $(1973,1975)$ which were treated with respect equal to that applied to discoveries concerning the species along the coasts of the Arctic Ocean. These Norwegian studies mentioned seem to indicate that the "Svalbard charr" shows certain differences, particularly in its biology, which set it apart from the others. 
Doubts as to the question whether the Svalbard form of the species is identical with those from other areas of the range as well as the logistic and financial support provided by the Polish Academy of Science (PAS Arctic Research Station on Hornsund Fjord, Vest Spitsbergen) prompted a team of researchers from the Faculty of Marine Fisheries and Food Technology, Academy of Agriculture in Szczecin to undertake a relatively comprehensive study on a homogenous material with the aim of elucidating the peculiarities of the Arctic charr and deciding if, and to what extent, the Svalbard population differs from the others. The presence of such differences could be assumed given the geographic isolation and, although weak, the observable impact of the Gulf Stream, coupled with considerable hydrological and physiographic diversity of the small archipelago of Svalbard.

The study materials consisted of male and female individuals caught in the summer seasons in the Hornsund region of Vest Spitsbergen; the capture sites included a river mouth area (River Revelva) and lakes (Revvatnet and Svartvatnet).

The papers published in this volume deal with morphology, osteology, growth rate, gonad maturity, fecundity, food and feeding, and parasitic fauna of the Arctic charr and also on heavy metal and fluoride contents in its tissues.

As seen from the list of topics covered, each paper, taken separately, contains a narrow range of information. However, the fact that they concern the same material has presented a unique opportunity of putting forward cohesive generalizations and broad conclusions.

The results reported show that the Artic charr from Svalbard is much more diversified morphologically than populations of the species living in other parts of the range, the diversification being a derivative of growth rate differences which, in turn, are brought about by living conditions. The morphological diversification is accompanied by differences in skeletal structures.

The remarkably wide range of differences in morphology and anatomy of the Arctic charr from Svalbard depends, obviously, on very changeable (and occasionally extremely harsh) environmental conditions (temperature, salinity, ice cover, quality and availability of food etc.). The wide range of structural differences of the population is indicative of its extraordinary biological plasticity which has enabled its persistence on this geographically isolated, physiographically and hydrographically differentiated, relatively small area.

It seems that the differences in the skeletal structure might have been brought about - in addition to biotic factors - by, in some instances adversely high, contents of fluoride and heavy metals as the waters around and on Spitsbergen are not at all free from those substances. The presence of heavy metals in the Arctic charr tissues, sometimes in concentrations similar to those observed in Baltic salmonids, points to ecological threats confronting this island in the Far North. The threats stem from the impact of the Gulf Stream and air masses brought by cyclones from faraway areas, 
and intensive - and on occasions inadequately controlled - human activities on the island.

It seems that both in the name of science and for the common good, the Arctic charr from Svalbard should be completely protected as an indicator organism of a kind, helpful in evaluating the ecological dangers the archipelago has to face.

\section{ACKNOWLEDGEMENTS}

As the project leader and on behalf of the authors of papers published in this volume I would like to thank the directors of the Polish Academy of Sciences' Institute of Ecology and Department of Polar Studies, namely Professors Romuald Klekowski, Ph.D., D.Sc., Stanisław Rakusa-Suszczewski, Ph.D., D.Sc., and Dr. Maciej Zalewski for the financial support and opportunity to use the facilities of the Polish Arctic Station in Hornsund. I wish also to acknowledge the Norwegian administrators of Svalbard for their friendly attitude towards participants of Polish expeditions to Spitsbergen, including our envoys.

Quite separately, my sincere thanks go to my close collaborators, Ms. Marta Stan'kowska-Radziun, M.Sc. and Dr. Krzysztof Radziun for their efforts, devotion, and involvement they have expended while working under dangerous conditions of the Far North to collect, preserve, and transport the materials which served as the basis for all the papers published in this volume.

\section{REFERENCES}

Berg LoSog 1948: (The freshwater fishes of the USSR and adjacent countries), Izd. AN SSSR, Moskva (In Russian).

Essipor V.KRo, 1952: (The fishes of the Karelskoe Sea), Izd. AN SSSR, Moskva (In Russian).

Gullestad Nog 1973: Freshwater biological studies in Svalbard 1962-1971. - Fauna, 26: 225-232 (In Norwegian).

Gullestad Nog 1975: On the biology of charr (Salmo alpinus L.) in Svalbard. Migratory and nonmigratory charr in Ravvatnet. - Not. Polarinst. Arbok:: 125-140.

Johrson Log 1980: The arctic charr Salvelinus alpinus. In: Charrs. Salmonid fishes of the genus Salvelinus. [K. Balon, ed.], The Hague, $1980: 15-98$.

Koljusher AoIo, 1971: Some osteological characters of charrs and "palijas" (genus Salvelinus) at north-west of the USSR in connection with their taxonomy. - Vopr. Ichtiol., 11:565-574 (in Russian).

McPhail J.W., 1961: A systematic study of the Salvelinus alpinus complex in North America。 - J. Fish. Res. Bd. Canada, 18: 793-816.

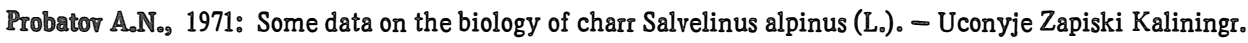
Univ., 6:24-30. (in Russian). 
Savvaitova KoAog 1976: On sympatric morpho-ecological groups in charrs of the genus Salvelinus (Salmonidae). - Zool. Zhurn., 55: 1677-1688. (in Russian).

Translated: Dr T. Radziejewska

Author's address:

Received: 1991.05.24

Prof. dr Aleksander Winnicki

Zakład Anatomii i Embriologii Ryb

Akademia Rolnicza

ul. K. Krölewicza 4, 71-550 Szczecin

Polska (Poland) 